\title{
Apresentação - Dossiê História e Historiadores
}

Presentation - History and Historians Dossier

Marcelo de Araújo Rehfeld Cedro*

É com intensa satisfação que publicamos o Dossiê História e Historiadores, a mais recente edição da revista Cadernos de História.

Amplas temáticas e abordagens são recorrentes objetos de análise no âmbito da atividade historiográfica e estão em contínuo debate no meio acadêmico. No entanto, já há algum tempo, o estudo sobre os historiadores vem despertando cada vez mais atenção e ocupando maiores espaços no campo de interesse dos pesquisadores, sobretudo na vertente das histórias intelectual, política, social e cultural. Neste dossiê optamos em destacar o papel ativo desempenhado pelos historiadores na produção do saber histórico, na seleção e no tratamento das fontes e na realização dos procedimentos metodológicos que bem fundamentaram as interpretações historiográficas sobre seu objeto de pesquisa.

Nessa perspectiva, convidamos para apresentar nosso editorial a dupla de historiadores Sérgio da Mata e Sabrina Magalhães Rocha. Os pesquisadores traçam um dinâmico percurso do que denominam 'história dos historiadores' a partir das transformações sofridas pelas meta-narrativas em novas abordagens micro e pluridisciplinares. Desde então, os autores convidam nossos leitores a um instigante raciocínio acerca da produção do conhecimento histórico na contemporaneidade.

Os dois artigos que abrem esse dossiê, "A África antiga sob a ótica dos clássicos gregos e o viés africanista" e "O mundo ibérico e as origens das relações com a África negra”, escritos, respectivamente, por Maria Regina Cândido e Luciano Borges Muniz,

\footnotetext{
* Doutor em Ciências Sociais pela Pontifícia Universidade Católica de Minas Gerais (PUC Minas). Professor do Departamento de História da PUC Minas. Editor Gerente dos Cadernos de História.
} 
pontuam algumas visões historiográficas envolvendo a história africana. A primeira pesquisa, além de destacar a legislação federal que instituiu de forma obrigatório os estudos africanos no Brasil, apresenta a relação entre o afrocentrismo e o eurocentrismo tendo como recorte temporal a África pré-moderna, sobretudo espelhando-se nas imagens construídas por 'historiadores' do mundo clássico. Já a pesquisa de Luciano Muniz amplia a vertente historiográfica, tradicionalmente concentrada na visão econômica, ao relacionar expansão marítima do século XV com a África subsaariana. Para o autor, outras abordagens transdisciplinares também marcaram a aproximação entre o mundo ibérico e o continente africano.

O próximo artigo, de autoria do pesquisador Luiz Francisco Albuquerque de Miranda, também se inclina em estudar a historiografia da expansão marítima ibérica do século XVI, porém, com o olhar da Ilustração do século XVIII, ao dar especial atenção à obra do abade francês Guillaume-Thomas Raynal. Com o título "História das duas Índias e os colonizadores da América", o autor analisa como a histórica filosófica do século XVIII representou os colonos ibéricos que chegaram à América a partir do século XVI.

Em seguida, o artigo de Aruanã Antônio dos Passos, intitulado "Do Império à República: escrita poética e biografia em Tobias Barreto (1869-1889)", apresenta interfaces da história com a literatura. Nesta pesquisa, o autor analisa a vida intelectual do emblemático escritor Tobias Barreto, conjugada à sua vida privada e ao contexto histórico do último quartel do século XIX. O próximo artigo, de autoria do pesquisador Alexandre Almeida Marcussi, cujo título é "O anticolonialismo como tragédia: os jacobinos negros entre a História e a política”, apresenta a obra do historiador antilhano de Trinidad e Tobago, Cyril Lionel Robert James, publicada no final da década de 1930. Marcussi destaca que o texto do ensaísta caribenho integrou o movimento panafricanista do século XX ao estimular o ativismo político negro daquele continente, em razão de oferecer uma das possibilidades historiográficas do violento processo de independência da colônia francesa de São Domingos e, consequentemente, a formação do Haiti em 1804, dando início à configuração dos Estados latino-americanos do oitocentos.

O próximo artigo que integra esse dossiê é de autoria do historiador Rafael Nascimento Gomes e se denomina "Seignobos x Simiand: a querela do método histórico com a ciência social no início do século XX". Como o título sugere, trata-se de um embate intelectual travado entre o historiador Charles Seignobos e o sociólogo e 
economista François Simiand. Para o pesquisador, tais discussões embasadas no método histórico e na ciência social foram fundamentais na institucionalização e na profissionalização dessas disciplinas no campo acadêmico francês. Na sequência, apresentamos o trabalho de Eduardo José Santos Borges e Augusto Fagundes da Silva dos Santos, intitulado "Considerações sobre um campo disciplinar: os principais modelos explicativos da economia colonial”. Os coautores lançam mão da bibliografia referencial acerca da dinâmica socioeconômica do período colonial brasileiro e realizam breve comparação historiográfica sobre essa temática. Nomes como Caio Prado Jr., Celso Furtado, Fernando Novais, Jacob Gorender, Ciro Flamarion Cardoso, João Fragoso e Manolo Florentino, são confrontados para confirmar o que já é amplamente reproduzido no meio acadêmico desde meados dos anos 1980: uma historiografia renovada ao considerar o contexto colonial como parte dinâmica e ativa de uma complexa rede econômica, política e social integrante do império português.

Parafraseando o historiador Lucian Lebvre ao afirmar que a 'História é filha de seu tempo', o próximo artigo desse dossiê, de autoria de Lucas Pereira de Oliveira, realça que, atualmente, o entendimento da História não se orienta por dogmatismos e inquestionáveis verdades. Pelo contrário, acentua o debate ao reconhecer as várias interpretações, posicionamentos, metodologias, escolhas e experiências do historiador incorporado ao seu tempo histórico e social. Assim, "E. P. Thompson entre fragmentos, embates e tensões: reflexões teórico-metodológicas do seu posicionamento frente aos escritos de Anderson, Nairn e Kolakowski", como bem sugere esse título, debate sobre várias questões historiográficas a partir do ponto de vista desses intelectuais marxistas.

$\mathrm{Na}$ sequência, o historiador José Costa D’Assunção Barros, no artigo “Os historiadores e o tempo: a contribuição dos Annales", discute, dentre outras abordagens, o conceito de 'longa duração', a partir da perspectiva da Escola dos Annales, utilizandose, sobretudo, das concepções de Marc Bloch, Fernando Braudel e Michel Vovelle acerca do tempo histórico. Já o artigo de André Fabiano Voigt -, intitulado "Jacques Rancière e a História: uma introdução" -, dialoga com a historiografia francesa no tocante às contribuições multidisciplinares do intelectual Jacques Rancière ao aproximar história, filosofia e literatura. No propósito de analisar a historiografia do sistema econômico mundial, apresentamos o artigo do pesquisador Carlos Leonardo Kelmer Mathias, “A Longa Duração, A Grande Divergência e A Grande Convergência: sumários apontamentos acerca da influência de Fernand Braudel na compreensão do atual sistema econômico mundial". Neste trabalho, como bem informado no título, o autor dialoga 
com a perspectiva braudeliana para pontuar aspectos consideráveis que delinearam o caminho tomado pelo cenário capitalista a partir do mundo moderno. E por fim, o artigo "Para uma historiografia do operariado de Alagoas", de Ivo dos Santos Farias encerra essa sequência, ao apresentar um percurso historiográfico acerca do movimento operário alagoano dialogando com a produção acadêmica de três gerações de estudiosos.

Realizada por este editor em parceria com o pesquisador Euclides de Freitas Couto, a próxima seção do dossiê apresenta a entrevista com a historiadora Lucília de Almeida Neves Delgado acerca de sua trajetória acadêmica e suas perspectivas historiográficas. Em seguida, destacamos o duplo trabalho de Pedro Spínola Pereira Caldas ao apresentar a comunicação "A filosofia da história universal de Friedrich Schiller: uma introdução", e a respectiva tradução do texto deste mesmo intelectual "O que significa e com que finalidade se estuda História Universal?”

Finalizamos a publicação desta edição com duas resenhas. A primeira, realizada por Matheus Landau de Carvalho, do livro "A eternidade pelos astros", escrito na prisão por Louis-Auguste Blanqui, ativista francês e participante da Comuna de Paris em 1871. A edição brasileira foi publicada em 2016, cuja tradução foi realizada por Luciana Persice. A outra resenha que integra este dossiê é apresentada por Alex Rogério Silva, do livro organizado por Ângela Vaz Leão, intitulado "Cantigas autobiográficas de Afonso X, o sábio". Trata-se de uma antologia traduzida e analisada de 34 poemas medievais referentes ao culto mariano.

Assim, através dos colaboradores deste dossiê temático, podemos destacar que a produção historiográfica e sua relação com os historiadores integram um vasto campo de possibilidades permeadas por conjunturas, espacialidades e tendências.

Desse modo, Cadernos de História ratifica ser um amplo espaço de discussão acadêmica que contribui com o diálogo transdisciplinar ao reunir neste número instigantes pesquisas sobre História e Historiadores.

Agradecemos mais uma vez a equipe do Setor de Revisão da PUC Minas, especialmente, a professora Daniella Lopes e aos estagiários Gabriel Gama e Francine Brandhuber. Agradecemos também a professora Jacyra Parreiras, chefe do Departamento de História da PUC Minas, e ao diretor da Editora PUC Minas, professor Paulo Agostinho Nogueira Baptista. Agradecemos ainda aos membros do Conselho Editorial dos Cadernos de História e, especialmente ao ex-editor adjunto Rafael Pacheco Mourão que, recentemente se desligou da revista e muito colaborou com seus serviços 
prestados ao longo desses anos para que este periódico acadêmico obtivesse o amplo reconhecimento institucional. Ressaltamos que todas essas pessoas foram importantíssimas para tornar possível mais uma publicação dos Cadernos de História.

Desejamos a todos uma boa leitura! 